\title{
The Elusiveness, Loss and Cruciality of Recovered Holiness: Some Biblical and Theological Observations
}

\author{
JASON GORONCY*
}

\begin{abstract}
While holiness is one of the motifs in theological discourse that can legitimately be said to entwine many others, the coinage it receives for such honour is being largely exiled from discussion. Thus, any contribution that could be made by considering Jesus Christ as the defining revelation of holiness is sidelined. Beginning with some biblical observations, and enlisting some help from Scottish Congregationalist P.T. Forsyth, this article seeks to encourage a reclaiming of holiness vocabulary as a distinctly christological reality and gift that finds expression first in the unique incarnate life and death of the Son, and then in the life and mission of the community created and sustained by that same Son.
\end{abstract}

\section{The elusiveness of a concept}

In Plato's famous discussion between Socrates and Euthyphro, Socrates asked: 'Try to answer more clearly what I asked you just now. You see, when I asked you before what holiness is, you didn't adequately explain it .... In a world in which the gods agree on almost naught, Euthyphro's response is that holiness is that of which all the gods approve, and what the gods approve is determined by what is holy: 'What is agreeable to the gods is holy, and what is not agreeable is unholy.' ${ }^{1}$ Although as their discussion develops it becomes clear that holiness is understood synonymously with piety, the interchange is a helpful illustration of the difficulty with, and antiquity of, the quest for an adequate definition of holiness. Unsurprisingly, Socrates and Euthyphro end up in a place similar to many theologians, at least those few who have

* School of Divinity, University of St Andrews, South Street, St Andrews KY16 9JU, Scotland, UK.

1 Plato, The Last Days of Socrates, trans. H. Tredennick and H. Tarrant (London: Penguin, 2003), pp. 15-16. 
embarked on the same quest. So Socrates: 'Thus you appear to me, Euthyphro, when I ask you what is the essence of holiness, to offer an attribute only, and not the essence - the attribute of being loved by all the gods. But you still refuse to explain to me the nature of holiness.' ${ }^{2}$

Given the centrality of divine (and creaturely) holiness in the 'holy' Scriptures, ${ }^{3}$ one is surprised to observe that Christian theologians have made very little of the idea in their theology proper. ${ }^{4}$ While copious material is available on God's righteousness, faithfulness and love, the extra-biblical tradition betrays a lack of reflection on holiness - specifically divine holiness. Where such is offered, the tradition tends to relinquish 'holiness' grammar for more familiar or accessible concepts of righteousness, goodness, truth and glory, ${ }^{5}$ or of God's perfections, and not infrequently to the practical abandonment of 'holiness' grammar altogether. Alternatively, holiness is used to consummate, unify and harmonize all incomparable divine attributes. ${ }^{6}$ Typically, what most definitions fail to offer (even some which purport to be 'Christian') is any clarity over the locus of revelation of God's holiness in Jesus Christ, the incarnate Son.

2 Plato, The Trial and Death of Socrates: Four Dialogues, trans. B. Jowett (New York: Dover, 1992), p. 11.

3 See Abraham J. Heschel, God in Search of Man: A Philosophy of Judaism (New York: Farrar, Strauss and Giroux, 1955), p. 244.

4 Webster helpfully identifies some of the reasons for this neglect. John Webster, Holiness (Grand Rapids: Eerdmans, 2003), pp. 34-5.

5 See John A. Motyer, The Prophecy of Isaiah (Leicester: IVP, 1993), p. 77; David Peterson, Possessed by God: A New Testament Theology of Sanctification and Holiness (Leicester: Apollos, 1995), p. 18; William Blake, 'A Vision of the Last Judgement', in D.R. Erdman, ed., The Complete Poetry and Prose of William Blake (Berkeley: University of California Press, 1982), p. 566.

6 See John of Damascus, On the Orthodox Faith 1.14 (NPNF2 9:17); John Calvin, Institutes of the Christian Religion, 1.10 .2 and 3.20.41; Jonathan Edwards, A Treatise Concerning Religious Affections (Philadelphia: James Crissy, 1821), pp. 196-9; Heinrich Heppe, Reformed Dogmatics: Set Out and Illustrated from the Sources, ed. E. Bizer, trans. G.T. Thompson (Grand Rapids: Baker, 1950), pp. 92-3; Jacob Milgrom, Leviticus 1-16: A New Translation with Introduction and Commentary (New York: Doubleday, 1991), pp. 731-2; Philip P. Jenson, Graded Holiness: A Key to the Priestly Conception of the World (Sheffield: Sheffield Academic Press, 1992), p. 48; Saul M. Olyan, Rites and Rank: Hierarchy in Biblical Representations of Cult (Princeton: Princeton University Press, 2000), pp. 15-37. Some theologians have sought to distinguish between God's 'essential holiness' and his 'moral holiness', i.e. between who God is in se, and in his actions. The Puritan John Howe termed God's holiness a 'transcendental attribute' which 'runs through the rest, and casts a glory upon them'. It is 'an attribute of attributes'. James Marsh, Select Practical Works of Rev. John Howe and Dr. William Bates (New York: G. \& C. \& H. Carvill / Burlington: Chauncey Goodrich, 1830), p. 57. The consensus is that holiness is concerned with more than mere purity of being. Douglas has convincingly argued that holiness means more than separation to divine service. It also means wholeness and completeness. Mary Douglas, Purity and Danger: An Analysis of Concepts of Pollution and Taboo (London: Routledge, 2002), p. 52. 


\section{The centrality of holiness in the Hebrew Bible}

Holiness has to do first and foremost with God. Its language is not borrowed from the realm of any human experience and is consequently (and uniquely) free from all logic of metaphor. Unable to be either translated or substituted for any other word, its meaning therefore can only be determined within the dynamic of divine action which it both reveals and mediates, even while it veils. Unsurprisingly, therefore, the vocabulary of divine holiness is most clearly preserved in the language of liturgy and prayer - in those arenas of human activity where God is spoken to rather than spoken about, where God is realized and praised rather than analysed and appraised, and where the burden of precise definition and explanation is not only less pressing, but if pressed could be disadvantageous and distorting. ${ }^{7}$

The naming of this risk does not shut down systematic enquiry, however, so much as define a proper context in which the discourse might proceed with humility. That systematic enquiry is, in fact, opened up by holiness is itself telling that holiness ever desires to be found and, indeed echoed. Accepting for the moment, then, the most common etymological ${ }^{8}$ meaning of holiness as 'sheer difference from everything else', ${ }^{9}$ or 'that which is marked off, withdrawn from ordinary use', ${ }^{10}$ and noting that holiness encompasses a far broader range of ideas and experiences than its etymology envelops, this 'otherness' finds twofold ethical expression in the Hebrew Scriptures - negatively, in its rejection of all that is opposed to God, and positively, in the sanctifying election of things, people and places other than God those creaturely realities that pertain to God.

Regarding the latter, Procksch helpfully identifies two discernible streams in the Hebrew Bible: the cultic (religious) and the prophetic (ethical). In the cultic, the focus is not on holy action but on holy states and holy objects - 'the holy things of the Lord'. As these objects combine with the cultus, eventually the cultus itself becomes threatened by a 'purely material conception of holiness', ${ }^{11}$ a materialization that was simply assumed by the time of Jesus (Mt. 23:17-19). As this materializing

7 I am not here advocating liturgical 'fuzziness', nor the confusion of 'mystery' with such.

8 See Norman H. Snaith, The Distinctive Ideas of the Old Testament (London: Epworth Press, 1947), pp. 21-42.

9 Colin E. Gunton, The Christian Faith: An Introduction to Christian Doctrine (Oxford: Blackwell, 2002), p. 49. YHWH is not, however, Israel's 'other'. See Christopher R. Seitz, Word Without End: The Old Testament as Abiding Theological Witness (Grand Rapids: Eerdmans, 1998), p. 23.

10 Walther Eichrodt, Theology of the Old Testament, vol. 1, trans. J. Baker (London: SCM Press, 1961), p. 270; cf. Gordon J. Wenham, The Book of Leviticus (Grand Rapids: Eerdmans, 1979), p. 19.

11 O. Procksch, 'œ́ $\alpha 10 \varsigma$ ', in Gerhard Kittel, ed., Theological Dictionary of the New Testament, vol. 1, trans. G.W. Bromiley (Grand Rapids: Eerdmans, 1964), p. 90; cf. Donald W. McCullough, 'Holy God, Holy Church', in Christian D. Kettler and Todd H. Speidell, eds., Incarnational Ministry: the presence of Christ in Church, Society, and Family: Essays in Honor of Ray S. Anderson (Colorado Springs: Helmers \& Howard, 1990), pp. 16-31. 
of holiness occurs in regard to God, holiness loses its static connotation and is personalized. Eventually, 'holiness' becomes a synonym for God. It is how we name him - he is the 'Holy One'. So, for example, Amos can speak of God swearing 'by his holiness' (Amos 4:2), that is, 'by himself' (6:8).

The ethicization of the holy comes to fruition in the prophets, most prominently in Isaiah where the (vertical) basis of Leviticus' Holiness Code - 'You shall be holy, for I the LORD your God am holy' - is worked out horizontally in the ethical and social life of God's people. Thus is God's name hallowed not just in Israel but before the nations, their 'job description' being Exodus 19:5-6. ${ }^{12}$ The prophets specifically identify this hallowing activity with Israel's care for its most vulnerable (refugees, orphans, widows and the poor), with just practices in the courts, and with other activities such as Sabbath observance and denunciation of idolatry. What this suggests is that holiness must echo itself, and it 'finds' that echo not only in its own Triune communion, but in creation.

\section{The annihilating power of holiness}

Creation's holiness, however, is not reached apart from judgement - the judgement of both Israel and the world. Hosea reminds us that although the 'Holy One of Israel who lives among you' has always desired 'steadfast love and not sacrifice' (Hos. 6:6), and shown mercy towards an ungrateful people, when God's covenant people defile themselves through sin and idolatry (5:3; 6:10) their unfaithfulness cannot finally go unpunished. Although such punishment tears at the very heart of God (6:4), Hosea warns that 'the days of punishment have come' upon idolatrous Israel (9:7) and such will be the intensity of that punishment that they will long to be crushed by the mountains (10:8; cf. Mk 13:14). Yet through this action of the Holy God come the raw words of a wounded lover who will not, and can not, let go of his beloved precisely because he is God and no mortal (11:8-9). Commenting on God's holiness in the book of Hosea, Eichrodt writes:

There can be no playing down the annihilating power of holiness, and the intensity of the threat of judgement in Hosea can hardly be exaggerated. Nevertheless, in the end it is the incomprehensible creative power of love which marks out Yahweh as the wholly 'other', the one whose nature is in complete contrast to that of the created cosmos. ${ }^{13}$

'Who among us can dwell with the consuming fire?', ask the trembling godless (Isa. 33:14). But who could dwell at all without him? The holy love of God overcomes the antithesis between himself and a world of rebels. Just as Isaiah saw 'in the year that King Uzziah died', God's holiness is the source of both our moral

12 See William J. Dumbrell, Covenant and Creation: A Theology of the Old Testament Covenants (Grand Rapids: Baker / Carlisle: Paternoster Press, 1993), pp. 87-90.

13 Eichrodt, Theology of the Old Testament, p. 281. 
estrangement (judgement) and our reconciliation. The Holy One is Israel's Redeemer. What Isaiah's eye did not yet see, nor ear hear, nor heart imagine, on that day, was that the Holy One of Israel is the world's Redeemer. Both Israel's calling to be a 'holy nation' and her judgement is with a view to the salvation of all the nations, to that day when the nations shall see God's righteousness in Israel's Messiah, and all the kings his glory (Isa. 62:2).

\section{Holiness incarnate}

God's holiness, like his love, is revealed in the economy of his action. ${ }^{14}$ The locus of this holiness-revealing activity was that nation birthed from slavery by the mercy of God and put out to live as the holy nation among all the nations to bear witness to the one true God (Ex. 15:11; 19:5-6). In the incarnation, that locus shifted as holiness tabernacled among us in Jesus Christ. At Pentecost, that locus was extended to those whom Jesus is not ashamed to call his sisters and brothers. Those who were once "no people' have come to the living Stone and are now 'a chosen race, a royal priesthood, a holy nation, a people for his own possession, that [they] may proclaim the excellencies of him who called [them] out of darkness into his marvelous light' (1 Pet. 2:9).

Few, if any, theologians have so trumpeted the centrality of holiness as Peter Taylor Forsyth (1848-1921). Whereas Bray argues that holiness is not only the quality peculiar to God's very essence, but finally an incommunicable quality, ${ }^{15}$ Forsyth posits the notion that in Jesus Christ, and in him alone, such a miracle happens - God's incommunicability is communicated: 'The unapproachable approaches, enters, tarries, lives, dies, conquers among us and in us . . subdues all things to its sanctity, and establishes its good and blessed self in us and on us all' ${ }^{16}$ Rejecting the impersonal Aristotelian formulations of holiness which found voice in Plotinus and Spinoza and later in Protestant and Roman scholasticism, which posited God as 'the Supreme Being, inviolable, self-sufficing, and splendid', Forsyth gives holiness a "true Christian sense' ${ }^{17}$ - a deliberately christological shape - when he regards Jesus as 'God's holiness in human form' ${ }^{18}$ Christ unveils God's holiness to

14 See John D. W. Watts, Isaiah 1-33 (Waco: Word, 1985), p. 74.

15 Gerald L. Bray, Holiness and the Will of God: Perspectives on the Theology of Tertullian (London: Marshall, Morgan \& Scott, 1979), p. 66.

16 Peter T. Forsyth, The Principle of Authority in Relation to Certainty, Sanctity and Society: An Essay in the Philosophy of Experimental Religion (London: Independent Press, 1952), p. 6.

17 Peter T. Forsyth, The Church, the Gospel and Society (London: Independent Press, 1962), p. 19.

18 Peter T. Forsyth, The Person and Place of Jesus Christ: The Congregational Union Lecture for 1909 (London: Congregational Union of England and Wales / Hodder \& Stoughton, 1909), p. 347. Barton has made a similar observation, noting that in the incarnation, holiness was dislocated and relocated, extended and intensified, in a person. 
us - not as a prophet with a message, but as the Son for whom nothing was dearer than his Holy Father and for whom nothing was more paramount than hallowing his Father's name.

The tradition has always maintained that holiness has no meaning apart from God. God is ontologically holy. Indeed, holiness is the one reality about God that is without parallel (metaphor) from within the created order. So it ought to come as no surprise that holiness can only be conceived by revelation - by giving itself to us. That God does precisely this is an expression of his freedom to be for and with the creature. That this 'giving' happens in his beloved Son is assurance that God's sovereign holiness is that which stoops down to us in merciful condescension and at great cost. Hence God's holiness never means that God is less gracious.

It is not only for theology proper that holiness is the primary category. Because of God's action in Jesus Christ, the same must also be said about creation. For a Holy Creator, creation's raison d'être must be the 'reflection and communion of His own holiness' ${ }^{19}$ Whether God can secure this 'holy destiny' in the face of that sin which mocks and smites holiness is, Forsyth contends, 'the ultimate question in life', because it is the question of final moral authority: ${ }^{20}$

Without such an absolute there is no faith, no obedience, because no authority. If it be not holy it is not a moral absolute; and if it do (sic) not save it does not love. Mankind finds and confesses its one authority in a Holy God as a Saviour - in the Holy God, not viewed in a moral aesthetic as merely pure, but ethically, lovingly, and practically viewed, as saving and sanctifying, as absolutely mastering the world's one moral crux, its unholy $\sin .{ }^{21}$

An imperative for understanding Forsyth's theology is that Jesus' holiness exposes the sin of the world and draws it to its hideous climax and end on the cross. One example, among many, where Forsyth attends to this reality is in his sustained commentary on Holman Hunt's painting of 1854, 'The Scapegoat'. Forsyth sees in this work the despised Christ groaning and travailing under the load and curse of the world's sin, knowing the horror or despair and confronting it 'head on'. Like Hunt's goat, Christ enters into hell, into the miasmal jungle of death, into the eretz gezerah

Stephen C. Barton, 'Dislocating and Relocating Holiness: A New Testament Study', in Barton, ed., Holiness Past and Present (London: T. \& T. Clark International, 2003), p. 197.

19 Forsyth, The Person and Place of Jesus Christ, p. 228. Again, Forsyth is with the tradition here. Gregory Nazianen, In Defense of His Flight to Pontus (NPNF2 7:204); Richard Baxter, Practical Works, vol. 15 (London: James Duncan, 1830), pp. 539-44; John Wesley, Works of Rev. John Wesley, vol. 7, ed. T. Jackson (London: Wesleyan Conference Office, 1872), pp. 266-8; Hans Martensen, Christian Dogmatics, trans. W. Urwick (Edinburgh: T. \& T. Clark, 1898), p. 92.

20 Forsyth, The Person and Place of Jesus Christ, p. 228; cf. Forsyth, The Principle of Authority, pp. 66, 405.

21 Forsyth, The Principle of Authority, p. 67. 
('place of cutting off', Lev. 16:22 22 ) where there is 'no life, but total curse, and hard, hopeless blight', ${ }^{23}$ carrying sin's curse 'amid fearful loneliness and agony, into the presence of God by confession full and complete; where the sin, being thus exposed, was purged and burned away in the forgiving love of God who is a consuming fire' ${ }^{24}$ Forsyth insists that while this scuppering of sin was a moral process, Christ's death is the crowning spiritual act of a succession of such obedient acts which flowed from a moral rather than a magical personality, and which constitutes his real spiritual life and work. ${ }^{25}$ Christ's death has meaning for us because he redeems from our midst, answering holiness 'from sin's side', and triumphs over evil through judgement, bearing the 'curse of human toil and sorrow' and absorbing into his own incarnate divinity all the judgement due to humanity. ${ }^{26}$

Here Forsyth reveals a development in the idea of holiness that is absent in Otto's mysterium tremendum, Tillich's 'the divine' or 'the quality of that which concerns man ultimately' ${ }^{27}$ and Derrida's 'unscathed which is safe and sound' ${ }^{28}$ Forsyth offers not the results of a particular reading of a universal religious, anthropological or cultural phenomenon, but a specifically Christian understanding of holiness whose content and definition is unapologetically Christ-given and shaped. Although he does play down the role of the Spirit, and despite his unapologetic Kantianism, Forsyth never considers divine holiness in isolation or in abstraction from God's sanctifying activity in Jesus Christ. To speak of 'the holy' is to speak of none other than One who has bared his holy arm in Jesus Christ and by the Holy Spirit as the 'Holy One in our midst', as our Redeemer and Sanctifier. In other words, we must never think of God's holiness (or human holiness) in abstraction from the action of the Triune God who elects, judges, saves and sanctifies humanity in Jesus Christ.

To affirm the Christ-given and -shaped characterization of holiness is to affirm that God's holiness is not the 'object' of our curiosity so much as the 'subject' of our life and being. So to reflect on the self-revelation of holiness is to be ever orientated towards and engaged in holy communion - a willed relationship of the holy with the Holy - a communion which is initiated, established, maintained and perfected by the Holy Trinity and secured forever in Christ's holy cross. ${ }^{29}$ We are saved into

22 The debate continues on whether this verse is better translated as 'a distant place'. See Wenham, The Book of Leviticus, pp. 233-5.

23 Peter T. Forsyth, Religion in Recent Art: Being Expository Lectures on Rossetti, Burne Jones, Watts, Holman Hunt, and Wagner (New York: AMS Press, 1972), p. 185.

24 Forsyth, Religion in Recent Art, p. 186.

25 Forsyth, Religion in Recent Art, p. 196.

26 The suffering that Christ endured was the penalty of sin itself, rather than God's punishment. Penalty alone, if not vicarious, only hardens and alienates.

27 Paul Tillich, Systematic Theology, vol. 1 (London: Nisbet, 1955), p. 239.

28 Jacques Derrida, 'Faith and Knowledge: the Two Sources of "Religion", , in Jacques Derrida and Gianni Vattimo, eds., Religion (Cambridge: Polity Press, 1998), p. 36. Cited in Webster, Holiness, p. 19.

29 See Peter T. Forsyth, The Work of Christ (London: Hodder \& Stoughton, 1910), p. 81. 
holiness - a holiness that is always, for humanity, 'borrowed' holiness, and is sustained by God.

To name God Christianly means that we cannot get away from holiness. Stephen Barton notes that holiness in the New Testament is related to an understanding of both 'who God is and where he is to be found', a sense of both his transcendent incomparability as well as his accessibility 'arising out of his covenantal love and mercy'. ${ }^{30}$ A survey of the aylos word group reveals at least four christological features. ${ }^{31}$ Firstly, although there is significant continuity between the testaments, in the New Testament holiness and sanctification take trinitarian shape. Central to this presentation is the person of Jesus. Sanctification still remains the sole work of God, but now it is that which has happened in the person of Jesus Christ. In this One who will be called 'holy' (Lk. 1:35; Mt. 1:21), and whom even the unclean spirits acknowledge as the 'Holy One of God' (Mk 1:24), God's holiness and glory have appeared enfleshed for the salvation of all, and in him human sanctification is secured. The Father has made Jesus our 'wisdom, righteousness, sanctification and redemption' (1 Cor. 1:30). There must be no mistake here of understanding salvation as merely the application of Christ's 'benefits'. What we have witness to in the New Testament is that in the incarnation, sinful human flesh has been taken up, united with God, crucified and purified from sin - made holy.

Secondly, a radical redefining of sanctification forms a central part of Jesus' ministry. We have no reason to suppose that Jesus did not presume some of the popular thinking central to much Second Temple Jewish piety - a piety which found expression both in ethical concerns as well as external conformity to social and cultic expectations. ${ }^{32}$ However, Jesus rigorously challenged and reinterpreted much of this thinking, not least those practices that excluded disreputable people from eating at the table of 'the righteous'. Here was no Qumran righteousness awaiting the coming of the kingdom. Here was One giving practical expression to the truth that in him the kingdom of God had dawned and with it good news for both 'sinners' and the 'righteous'. Not a few times did Jesus - in a similar manner to the pre-exilic prophets - accuse his contemporaries of being too concerned with outward piety at the expense of the 'weightier matters of the law: justice, mercy and faithfulness', calling

30 Barton, 'Dislocating and Relocating Holiness', p. 195.

31 This is not to deny the important New Testament material on the Father and Spirit as holy, nor that there is not much more that ought be said about holiness and the Son.

32 First-century Palestine witnessed a number of competing renewal movements within Judaism that extended to conflicting notions of holiness. It seems that Jesus' focus on the heart rather than on merely externals was basically unique to him, however, and appears to be a point of genuine divergence between Jesus and other expressions of holiness within the Judaism of his time. Those interested may wish to consult the following: Bruce Chilton and Craig A. Evans, eds., Jesus in Context. Temple, Purity, and Restoration: Arbeiten zur Geschichte des Antiken Judentums und des Urchristentums XXXIX (Leiden: Brill, 1997); Marcus J. Borg, Conflict, Holiness, and Politics in the Teachings of Jesus (Harrisburg: Trinity Press International, 1998), pp. 66-212; Peter J. Tomson, 'Jesus and his Judaism', in Markus Bockmuehl, ed., The Cambridge Companion to Jesus (Cambridge: Cambridge University Press, 2001), pp. 33-5. 
upon them to do the latter without neglecting the former (Mt. 23:23). Presumably, the lighter matters of the law will care for themselves as justice and mercy find adequate expression and priority.

Thirdly, in Jesus, God's holiness is not relaxed so much as brought near to those who were formerly on the outer - even to those outside Israel. The second Person of the Holy Trinity entered the matrix of Israel's cultically clean-obsessed society and deliberately set about to touch the unclean - lepers, corpses, menstruating women. He made a point of eating with prostitutes and calling 'sinners' his friends. He did almost everything that the Old Testament prohibits the people of YHWH, and especially priests, from doing. In his complete identification with us, he made himself not only common, but ceremonially unclean - bringing himself under the curse and judgement of God. In this action, he shifted the focus from the temple to his body, and from ritual cleanness to the human heart (Mk 7:15-23). As our High Priest, Jesus rightly discriminated between holy and common, between clean and unclean. As God, through whom all things were created, in becoming a creature he joined himself to the creation, died in it, and was resurrected in it. In that one living-dying-rising action he vanquished sin and death, and declared that humanity and creation are sanctified - made 'good' ${ }^{33}$ - as they find their life and identity in him.

Fourthly, Jesus made it clear (at least to those who are given to see) that the sanctification of all things and the establishment of God's kingdom would happen through the judgement of this world, through the ruler of this world being driven out, as Jesus is lifted up on the cross from where he will draw all people to himself. The interplay of the words 'holy', 'sanctify', 'glory' and 'glorify' in Jesus' high priestly prayer (Jn 17) point to the reality that the sanctification of the disciples and of the world (as past and completed action) flows from the action of the Son sanctifying himself at the cross (Jn 17:19). When he touched the 'unclean', he became the polluted One, the sick One, the crippled One, the adulterous One, the dying One, the One on whom all the wrath of God would fall. He became as the greatest sinner of all, though he was without any sin of his own, and he 'bore our sins in his body on the tree ... by his wounds we have been healed', that is, sanctified. ${ }^{34}$ Creation's disorder, chaos, pollution and guilt have been taken up in this Man who gathered all the cesspool of the confusion of human hell into the depths of his own being as he fulfilled the Father's will in becoming a curse for us. This is sin's 'supreme perversion ... . when innocents are condemned and die as if they were sinners'. ${ }^{35}$ And in his crucified humanity, he suffered all unholy corruption and guilt until it was annihilated. He made purification for our sins and in bringing us into the holy presence of God he sanctified us, and perfected us in himself. Not only does this One

33 See Karl Barth, Ethics, trans. G.W. Bromiley (New York: Seabury Press, 1981), p. 16.

341 Pet. 2:24; cf. John Chrysostom, Homilies on 2 Corinthians 5:11 (NPNF1 12:334).

35 Jean-Noël Aletti, 'God made Christ to be Sin (2 Corinthians 5:21): Reflections on a Pauline Paradox', in Stephen T. Davis et al., eds., The Redemption: An Interdisciplinary Symposium on Christ as Redeemer (Oxford: Oxford University Press, 2004), p. 116. 
of grace and truth purify Israel (Jn 2:1-22), but he taught his disciples to pray as those anticipating the restoration of all things and God's holy kingdom established everywhere forever.

Jesus is the Holy One of God (Mk 1:24; Lk. 1:35), the One set apart for God, that God's name (and so God) may be indisputably recognized as holy. To this end, Jesus must reveal God's holiness over all evil - human and otherwise - in judgement of an unholy creation. Forsyth plays on John's words: 'God so loved the world . . . that He gave His Son as a propitiation to His own holiness' ${ }^{36}$ God does not merely dispense judgement. He bears it, praises it, hallows it and absorbs it on the tree; and his resurrection announces that he exhausts it. ${ }^{37}$ Forsyth insists that in the obedient Son, God's love is hallowed, for it 'must be hallowed, even if [God] spare not His Son. His Son spared not Himself in the hallowing of that name. It was the first function of His Cross. ${ }^{38}$ God hallowed his own name in that one action that redeemed and sanctified all humanity. Indeed, he

owed it to Himself. 'I do not this for your sake, but for My holy name which ye have profaned.' In His love He gave the Self that makes Him what He is eternally, and is in Himself and of Himself. His holiness was able to make His own propitiation, which was so willing in His love. ${ }^{39}$

Holiness - God's and ours - is the theme in the ministry of Jesus and so of the Scriptures. It stands to reason then that Christianity's first concern be 'God's holiness before all else'. ${ }^{40}$ As it must if holiness is to be truly holy, God's holiness descends on humanity as love, assails sin as grace, and exercises grace through judgement. Forsyth sees in the atonement that action of Christ's death whose 'prime regard' and 'first charge' was to God's holiness. Human reconciliation is 'impossible except as that holiness is divinely satisfied once for all on the cross. ${ }^{41}$ Indeed, this goal is the key to the incarnation. He who shared the wrath of the Father (Rev. 6:16-17) as well as his love for humanity (Jn 3:16; 13:1), entered humanity to stand as humanity's vicar, answering the prayer 'Hallowed be thy name' at the cross. Never again can God be charged with indifference to evil against his name. Never again can humanity claim ignorance concerning the true nature of ethics as holiness. ${ }^{42}$

36 Peter T. Forsyth, The Justification of God: Lectures for War-Time on a Christian Theodicy (London: Independent Press, 1957), p. 109.

37 Forsyth, The Work of Christ, p. 190; cf. p. 243.

38 Forsyth, The Justification of God, p. 11; also pp. 115, 117.

39 Peter T. Forsyth, The Preaching of Jesus and the Gospel of Christ (Blackwood: New Creation Publications, 1987), p. 75; cf. pp. 100, 108-10.

40 Peter T. Forsyth, The Cruciality of the Cross (London: Hodder \& Stoughton, 1910), p. 5.

41 Forsyth, The Cruciality of the Cross, p. 5.

42 See Forsyth, The Preaching of Jesus, pp. 221-4. Forsyth repeatedly insists that the Gospel deals with the world and with life 'as a whole'. Peter T. Forsyth, 'Religion and Reality', Contemporary Review 115 (1919), p. 548. 'It argues the restoration of all things, a new heaven and a new earth. It intends the regeneration of human society as a whole. Christ is the Saviour of the world.' Forsyth, The Work of Christ, p. 171. It is this 


\section{Ethical implications of holiness - life in the Holy Spirit}

Karl Barth has noted that the 'problem' between the reconciliation and sanctification actualized in Christ and the contemporary situation of the Christian in the world is the 'divine problem' that God has taken up as his own and solved in the presence and action of the Holy Spirit. ${ }^{43}$ The Spirit is the beginning point for all our theology because he alone, through his Word written and proclaimed, reveals Jesus Christ and so something of the life that the Father shares with the Son. The Bible's own vocabulary concerning the Spirit's work includes his conviction of sin, assurance of forgiveness, guidance into the truth of the Scriptures and aid in prayer. It is the Spirit who builds, orders and empowers the church for its mission to the world, accompanies the preaching of the gospel, makes that preaching effective, binds us to Christ, and brings us to worship the Triune God through faith and obedience. Apart from the Spirit's work, there would be no gospel, no new birth, ${ }^{44}$ no unity among believers, no Bible, no knowledge of the Lord Jesus ${ }^{45}$ and no holiness. This is Scripture's way of giving voice to the reality that the Spirit alone may create the purlieus for borrowed and reciprocal holiness in that creation in which he is the life. This pneumatic action creates an eschatological correspondence to the Spirit's own holy nature, a correspondence which has already found enfleshment in Jesus Christ, and which the Spirit pledges to extend universally to all creation as the fulfilment of Christ's redemptive action. God's gift of two holy and creaturely realities - namely the holy church and holy Scripture - are both taken up into God's sanctifying activity serving as 'firstfruits' of God's determination to bring all of creation into blamelessness (Rev. 14:4).

The holiness of God revealed through the Spirit in the economy of the Son makes possible humanity's unity before God. Barton rightly notes that the reinterpretation of holiness in the epistle to the Hebrews in terms of a holiness of solidarity in God's relation with creation 'makes possible a new solidarity within the created order itself. The locus of this new solidarity is the Church. ${ }^{46}$ The church is the communio sanctorum not because of its self-confessed sanctity or fraternity but

world as the kingdom of Christ's holiness that shapes Forsyth's vision regarding such realities as the church, the home, the arts, issues of social justice, mission, politics, and society as a whole.

43 Karl Barth, Church Dogmatics IV/2, ed. G.W. Bromiley and T.F. Torrance; trans. G.W. Bromiley (Edinburgh: T. \& T. Clark, 1958), pp. 342-53.

44 Or 'old birth' for that matter.

45 The possibility of our experiencing Christ as present is only made possible because of the actuality of his presence in the power of the Holy Spirit. See Thomas F. Torrance, Theology in Reconstruction (London: SCM Press, 1965), p. 235. Smail reminds us that those who are inspired and empowered by the Holy Spirit not only have their roots in relationship to God but 'express themselves horizontally and practically in such a way as to challenge the oppressive structures of society in which the church lives'. Thomas Smail, The Forgotten Father (Grand Rapids: Eerdmans, 1980), p. 179.

46 Barton, 'Dislocating and Relocating Holiness', p. 208. 
because it belongs to Christ, because it is creatura verbi divini and lives by that same Word, because its very existence bears witness to God's saving and sanctifying purposes for all humanity, and because it participates in Jesus' own hallowing mission to the world in the power of the Spirit to the glory of the Father. Thus the church is holy not by its own choice but by the election of a holy God, and its redemption by a holy Christ. It is this calling that sanctifies the church and regulates it in its mission. Again Forsyth: 'The bride grows to meet the husband who chose her and whose rank she takes. Whom God called He also sanctified, and He has gone on sanctifying. Indeed, it is actually a holier Church to-day than in the first century. ${ }^{, 47}$

Holiness is never static, and so conferred ecclesial holiness finds ebullient though disciplined expression lived out in the power of the Holy Spirit in the world for which it is elected and set apart. This vocation is fulfilled in so far as the church bears witness not to itself but to its Holy Husband, and to his sanctifying work for and in the world. Thus can Forsyth assert that 'all history exists for the Church' ${ }^{48}$ Commenting on Romans 1:7, Cranfield writes:

The 'holiness' of God denotes the absolute authority with which He confronts men. But this authority was the authority of Him who had revealed Himself as merciful and righteous; and under the influence of the prophets the ethical element in 'the holy' was strongly emphasized. The term 'holy', applied to Israel, expressed the fact that they were God's special people. Their holiness derived from God's gracious choice, and it involved the obligation on their part to seek to be and do what was in accordance with the revealed character of their God by obedience to His law (see especially the 'Holiness Code' of Lev. 17-26). Paul's use of óyiors rests squarely on this OT foundation. Those who have been called by the holy God are holy in virtue of His calling and are thereby claimed for holiness of life. ${ }^{49}$

To be sure, in so far as the church is elected, called and equipped by God to live out its vocation in holiness in this world, and not some other world, here we enter the paradox so elegantly described by Rowan Williams:

A human being is holy not because he or she triumphs by will-power over chaos and guilt and leads a flawless life, but because that life shows the victory of God's faithfulness in the midst of disorder and imperfection. The Church is holy ... not because it is a gathering of the good and the well-behaved, but because it speaks of the triumph of grace in the coming together of strangers and sinners who, miraculously, trust one another enough to join in common repentance and common praise... Humanly speaking, holiness is always like

47 Forsyth, The Church, the Gospel and Society, p. 25.

48 Forsyth, The Principle of Authority, p. 354.

49 C.E.B. Cranfield, The Epistle to the Romans, vol. 1 (Edinburgh: T. \& T. Clark, 1975), p. 70 , emphasis mine. 
this: God's endurance in the middle of our refusal of him, his capacity to meet every refusal with the gift of himself. ${ }^{50}$

Forsyth properly reminds us that the holiness of the church is, like God himself, unseen, though manifest wherever the gospel which created it is lived and worked for, and where the measure of its true action - namely worship - is undertaken in all the energy and grace that flows from God towards humanity. 'In its purity it is everywhere to faith, nowhere to sight. ${ }^{51}$

Requisite to this witness is holy Scripture, the creation of that Word of God by which the church is born, sustained, chastened, reformed, equipped and sent into the world to fulfil its priestly and prophetic vocation, and through which Christ publishes his gospel. Scripture is holy because it is set apart for, and taken up by, the Spirit to this end - to testify perfectly concerning Christ (Jn 5:39). The Bible, therefore, is not so much a document as a holy sacrament. ${ }^{52}$

The Holy Father's goal for humanity, from before the foundation of the world, is a pure and holy family. This is the true nature of things. God's people are therefore claimed for holiness by God and called to live holy lives that reflect the holy communion that the Father knows with the Spirit and the Son - the definitive expression of which is love. As argued above, this claiming happens in the person of Jesus Christ. In him, and for his sake, the church, the 'holy temple', is sanctified and called to live out the reality of her sanctification in the world. Now fully sanctified through the death of her husband, unqualified obedience to his life-giving and holy word is not an option. Far from being a burdensome thing, it is the delight of those who love and reverence the God they call 'Holy Father'. This life of obedience is made possible because of, and through, the two gifts of the Father - the death/resurrection/ascension of the Son for us, and the subsequent pouring out of the Holy Spirit who realizes in the creature what has already been achieved for the creature. $^{53}$

The New Testament calls those so claimed for holiness of life 'saints'. These 'holy ones' make up the Holy Community. They are not, as even Otto reminds us, 'the morally perfect' so much as those who 'participate in the mystery of the final

50 Rowan Williams, Open to Judgement: Sermons and Addresses (London: Darton, Longman \& Todd, 1994), p. 136.

51 Peter T. Forsyth, The Church and the Sacraments (London: Independent Press, 1947), p. 49; cf. Peter T. Forsyth, Congregationalism and Reunion: Two Lectures (London: Independent Press, 1952), p. 14.

52 See Forsyth, The Principle of Authority, pp. 134-5, 372-4; Peter T. Forsyth, 'Churches, Sects and Wars', Contemporary Review 107 (May 1915), p. 620; Forsyth, The Church and the Sacraments, p. 132; Forsyth, The Church, the Gospel and Society, pp. 68-9, 125-7; Peter T. Forsyth, 'A Few Hints about Reading the Bible', Biblical Review 3 (1918), pp. 530, 542-3.

53 Inseparable from the work of Christ - both as enacted and as preached in the apostolic testimony (the Bible) - the Holy Spirit is given to the Church as Christ's 'greatest gift' and the 'fruit of His greatest act and consummation'. Peter T. Forsyth, Faith, Freedom and the Future (London: Hodder \& Stoughton, 1912), pp. 12-13. 
Day' ${ }^{54}$ Whilst some New Testament scholars, following particularly the epistle to the Hebrews, identify this activity as being determined by and mediated through the new Christ cultus, ${ }^{55}$ others are persuaded that the focus of this activity is the Holy Spirit. ${ }^{56}$ Those who have been sanctified in Christ are kept sanctified by the 'Spirit of holiness' who now leads the 'saints' by the word of God into truthful living, that is, 'walking' in a manner befitting their sanctification. ${ }^{57}$ Utilizing cultic imagery, Paul entreats believers to present their bodies as living sacrifices, 'holy (é $\gamma i \alpha v)$ and acceptable to God', as their reasonable ( $\lambda$ o $\gamma \iota \kappa \dot{\eta} v)$ act of worship (Rom. 12:1). This is only possible, he has already argued, as believers 'set their minds on the things of the Spirit' and dwell in him (8:5, 9-11), for 'those who are led by the Spirit of God are sons (vioi) of God' (8:14).

The indwelling of the Spirit means, negatively, 'effectual power in the struggle against sin', ${ }^{58}$ what was once called mortification, not in the sense of sinless perfection but in the sense that one is never left helpless. Positively, it means vivification - what Webster describes as the power to live 'out of that which has been made alive in the Son's resurrection'. ${ }^{59}$ The New Testament allows no room for a notion of holiness divorced from those ethical imperatives that the holy God calls his elect to live out and so empowers them for. God has given his Spirit precisely that the church might be empowered to resist the 'works of the flesh', manifest the fruitful life of God in the world, and so express true humanity as it stands blameless in Christ at his appearing. Thus it ought to be no surprise that the Holy Spirit is the eschatological Spirit. He is the point of interruption of the familiar with the yet familiar, that is, with the yet to come. Like holiness itself, the Spirit lies beyond the boundaries of what we yet fully know, even while ever bringing the truth of the future to us.

At a time when even conservative publishers are sponsoring work that questions the appropriateness of speaking of ' $\sin ,{ }^{60}$ the need for the one, holy, catholic and

54 Rudolph Otto, The Idea of the Holy: An Inquiry into the Non-Rational Factor in the Idea of the Divine and its Relation to the Rational, trans. J.W. Harvey (London: Oxford University Press, 1931), p. 86.

55 See Procksch, 'ó đ̊

56 Horst Seebass, 'óy Testament Theology, vol. 2 (Grand Rapids: Zondervan, 1986), pp. 223-9.

57 Paul removes the vocabulary of holiness from the province of the cult and makes it the responsibility of every believer. The impossibility of the 'unholy' being admitted into 'the happiness of heaven' is a recurrent theme in post-Reformation Protestantism, particularly in seventeenth-, eighteenth- and nineteenth-century evangelicalism. See, for example, Jonathan Edwards, 'The Way of Holiness', in The Works of Jonathan Edwards, vol. 10, ed. W. H. Kimnach (New Haven: Yale University Press, 1992), p. 475; Thomas Jackson, ed., The Works of John Wesley, vol. 10 (Grand Rapids: Baker, 1979), p. 364.

58 Gordon D. Fee, God's Empowering Presence: The Holy Spirit in the Letters of Paul (Peabody: Hendrickson, 1994), p. 53; cf. Alfred Plummer, A Commentary on St Paul's First (and Second) Epistles to the Thessalonians (London: Scott, 1918), p. 63.

59 Webster, Holiness, p. 88.

60 For example, Alan Mann, Atonement for a 'Sinless' Society: Engaging with an Emerging Culture (Milton Keyes: Paternoster, 2005). 
apostolic community to rediscover the centrality of holiness as the most quick, piercing, subtle, pervasive and permanent power we know - as it comes to us and is defined for us in the person of Jesus Christ - is imperative. ${ }^{61}$ I conclude with an assessment by David Wells, who has written of God's holiness in the face of what he adjudicates to be a loss manifested everywhere in the evangelical world of the vision of God as holy:

The loss of the traditional vision of God as holy is now manifested everywhere in the evangelical world. It is the key to understanding why sin and grace have become such empty terms. What depth or meaning, P.T. Forsyth asked, can these terms have except in relation to the holiness of God? Divorced from the holiness of God, sin is merely self-defeating behavior or a breach in etiquette. Divorced from the holiness of God, grace is merely empty rhetoric, pious window dressing for the modern technique by which sinners work out their own salvation. Divorced from the holiness of God, our gospel becomes indistinguishable from any of a host of alternative self-help doctrines. Divorced from the holiness of God, our public morality is reduced to little more than an accumulation of trade-offs between competing private interests. Divorced from the holiness of God, our worship becomes mere entertainment. The holiness of God is the very cornerstone of Christian faith, for it is the foundation of reality. Sin is defiance of God's holiness, the Cross is the outworking and victory of God's holiness, and faith is the recognition of God's holiness. Knowing that God is holy is therefore the key to knowing life as it truly is, knowing Christ as he truly is, knowing why he came, and knowing how life will end. ${ }^{62}$

61 Peter T. Forsyth, Missions in State and Church: Sermons and Addresses (London: Hodder \& Stoughton, 1908), p. 335.

62 David F. Wells, No Place for Truth: Or, Whatever Happened to Evangelical Theology? (Grand Rapids: Eerdmans, 1993), p. 300. 